Agropedology 2016, 26 (02), 189-197

\title{
The Major Biophysical Indicators of Desertification in Arid and Semi arid regions of India
}

\author{
S. Dharumarajan*, M. Lalitha, R. Vasundhara and Rajendra Hegde \\ ICAR-National Bureau of Soil Survey and Land Use Planning \\ Regional Centre, Bangalore-560024, India
}

\begin{abstract}
Desertification is a process of land degradation in arid, semi- arid and dry sub-humid regions due to climatic uncertainties and improper land management activities. The major desertification processes operating in arid and semi arid regions of India are soil erosion, vegetal degradation, salinization/alkalinisation, water logging, loss of soil fertility and uncontrolled mining. Identification of major biophysical indicators of desertification is necessary for periodical monitoring and preparation of strong combating plan. To investigate the biophysical indicators which are most effective in assessing the level of desertification vulnerability, a total of 17 biophysical indicators were studied in 13 sites of South India representing two different agro-ecological regions (AESR 8.3\&3). Principal Component Analysis was employed to identify the effective indicators based on maximum loadings and Eigen value. Linear discriminant analysis was used to identify the most important and reliable indicators for assessing degree of desertification processes. The results showed that $\mathrm{pH}$ and organic carbon are the most reliable indicators for assessing the degree of desertification processes in South India.
\end{abstract}

Keywords: Desertification, indicators, PCA analysis, organic carbon

\section{Introduction}

India occupies about $2.4 \%$ of the world's geographical area which supports $16.7 \%$ of the world's human population and about $0.5 \%$ of the world's grazing lands, supports $18 \%$ of the world's cattle population. Thus land resources are under severe pressure which leads to degradation and it is reported that $57 \%$ of land area in India has been already degraded (Sehgal and Abrol 1994). Recent report on desertification status mapping of India revealed that $82.64 \mathrm{~m}$ ha of arid, semi-arid and dry sub-humid regions of the country are affected by different desertification processes (SAC 2016). The major causes for land degradation / desertification in India are expansion of cultivation to lands of low potential, inadequate soil and water conservation measures, intensive cropping systems, soil and water pollution and over exploitation of ground water in addition to changing climate.

The status and degree of desertification vulnerability can be assessed indirectly by using selected indicators (Rajan et al. 2010; Kosmos et al. 2015).

*Corresponding Author Email: sdharmag@gmail.com
Higginbottom and Symeonakis (2016) reported that multitemporal analysis of different vegetation indices can provide status and severity of land degradation and desertification. The identification of valid and true indicators are very important which helps not only to identify the severity of desertification processes but also in monitoring and preparation of strong combating plan. Different approaches are followed at international level to identify the effective indicators of desertification (Kosmos et al. 1999). The indicators of desertification are mostly climate, soil, vegetation and management factors (Kosmas et al. 1999; Sivakumar 2007). Bergkamp (1995) used indicators related to water conservation for assessing desertification. Socioeconomic variables such as population density, population growth rate also has been included by some of the researchers as a potential indicator for assessment of desertification (Salvati et al. 2011 and Salvati and Zitti 2008). The major biophysical factors responsible for soil erosion, salinisation/alkalinisation, vegetal degradation and deterioration of soil fertility are collected from previous studies (Rajan et al. 2010; Naidu et al. 2014; Kosmos et al. 2015) and presented in Table 1. 
Table 1. Biophysical indicators of different desertification processes collected in study area

\begin{tabular}{|c|c|c|c|c|}
\hline Indicators & Soil erosion & $\begin{array}{l}\text { Salinisation/ } \\
\text { alkalinisation }\end{array}$ & $\begin{array}{l}\text { Vegetal } \\
\text { degradation }\end{array}$ & $\begin{array}{l}\text { Loss of soil } \\
\text { fertility }\end{array}$ \\
\hline \multicolumn{5}{|l|}{ Climate } \\
\hline Air temperature & $\checkmark$ & $\checkmark$ & $\checkmark$ & $\checkmark$ \\
\hline Rainfall & $\checkmark$ & $\checkmark$ & $\checkmark$ & $\checkmark$ \\
\hline Aridity index & $\checkmark$ & $\checkmark$ & $\checkmark$ & $\checkmark$ \\
\hline $\begin{array}{l}\text { Potential } \\
\text { evapotranspiration } \\
\text { Soil site characteri }\end{array}$ & $\checkmark$ & $\checkmark$ & $\checkmark$ & $\checkmark$ \\
\hline Slope & $\checkmark$ & $\checkmark$ & $\checkmark$ & $\checkmark$ \\
\hline Drainage & & $\checkmark$ & & $\checkmark$ \\
\hline Erosion class & $\checkmark$ & & $\checkmark$ & $\checkmark$ \\
\hline Surface fragments & $\checkmark$ & & $\checkmark$ & $\checkmark$ \\
\hline Rockout crops & $\checkmark$ & & $\checkmark$ & \\
\hline \multicolumn{5}{|c|}{ Soil morphological characteristics } \\
\hline Soil depth & $\checkmark$ & & $\checkmark$ & \\
\hline Soil colour & $\checkmark$ & $\checkmark$ & & $\checkmark$ \\
\hline $\begin{array}{l}\text { Surface horizon } \\
\text { thickness }\end{array}$ & $\checkmark$ & & & $\checkmark$ \\
\hline Soil texture & $\checkmark$ & & $\checkmark$ & $\checkmark$ \\
\hline Soil structure & $\checkmark$ & $\checkmark$ & $\checkmark$ & \\
\hline Presence of gravels & $\checkmark$ & & $\checkmark$ & \\
\hline \multicolumn{5}{|c|}{ Soil physical and chemical characteristics } \\
\hline $\mathrm{pH}$ & & $\checkmark$ & $\checkmark$ & $\checkmark$ \\
\hline $\mathrm{EC}$ & & $\checkmark$ & $\checkmark$ & \\
\hline $\mathrm{OC}$ & $\checkmark$ & $\checkmark$ & $\checkmark$ & $\checkmark$ \\
\hline CEC & $\checkmark$ & & $\checkmark$ & $\checkmark$ \\
\hline ESP & & $\checkmark$ & & $\checkmark$ \\
\hline $\mathrm{CaCO}_{3}$ & & $\checkmark$ & & $\checkmark$ \\
\hline $\mathrm{N}$ & $\checkmark$ & & & $\checkmark$ \\
\hline $\mathrm{P}$ & $\checkmark$ & & & $\checkmark$ \\
\hline K & $\checkmark$ & & & $\checkmark$ \\
\hline \multicolumn{5}{|c|}{ Land use Management } \\
\hline Land use & $\checkmark$ & $\checkmark$ & $\checkmark$ & $\checkmark$ \\
\hline Type of crop & $\checkmark$ & & $\checkmark$ & $\checkmark$ \\
\hline Tillage & $\checkmark$ & & $\checkmark$ & $\checkmark$ \\
\hline
\end{tabular}


For the present study, an attempt was made to identify the most important and reliable indicator for assessing the degree of desertification in two different agroecological regions (AESR $8.3 \& 3$ ) of south India using principal component analysis (PCA) method.

\section{Materials and Methods}

Description of the Sampling sites

Thirteen sites were identified in two different agroecological regions of Tamil Nadu and Andhra Pradesh for selection and identification of major biophysical indicators of desertification (Table 2). Two sites in Nanguneri block (Nanguneri and Rajakkamangalam), two sites in Sivagangai block (Malampatti and Tamarakki Vadakkur) and three sites in Kangeyam block (Vadasinnapalayam, Pappini and Palaiyakottai) representing agro-ecological sub region of 8.3 (Tamil Nadu uplands and plains hot moist semi-arid ESR) were selected from Tamil Nadu. Two sites (Muttala 1\&2) in Atmakur mandal and four sites in Bukkarayasamudhrum mandal (Bodagandodi, Kottapalle, Dayyadakuntapalle and Chennampalle of Anantapur district representing agroecological region of 3 (Karnataka plateau (Rayalseema as inclusion), hot arid ESR) were selected from Andhra Pradesh. Long term (30 years) average climatic parameters were collected from Indian Meteorological Department (IMD 2014).

Table 2. Sampling sites

\begin{tabular}{|c|c|c|c|c|c|}
\hline Site & Co-ordinates & Village & $\begin{array}{l}\text { Block/ } \\
\text { mandal }\end{array}$ & District & State \\
\hline \multicolumn{6}{|c|}{ AESR: 8.3, Tamil Nadu uplands and plains hot moist semi -arid ESR } \\
\hline 1 & $\begin{array}{l}8^{\circ} 28^{\prime} 41.4^{\prime \prime} \mathrm{N} \\
77^{\circ} 39^{\prime} 35.6 " \mathrm{E}\end{array}$ & Nanguneri & Nanguneri & Thirunelveli & Tamil Nadu \\
\hline 2 & $\begin{array}{l}8^{\circ} 25^{\prime} 55.8^{\prime \prime} \mathrm{N} \\
77^{\circ} 39^{\prime} 14^{\prime \prime} \mathrm{E}\end{array}$ & Rajakkamangalam & Nanguneri & Thirunelveli & Tamil Nadu \\
\hline 3 & $\begin{array}{l}9^{\circ} 57^{\prime} 6.9^{\prime \prime} \mathrm{N} \\
78^{\circ} 24^{\prime} 52.5^{\prime \prime}\end{array}$ & Malampatti & Sivagangai & Sivagangai & Tamil Nadu \\
\hline 4 & $\begin{array}{l}9^{\circ} 55^{\prime} 38.8^{\prime \prime} \mathrm{N} \\
78^{\circ} 23^{\prime \prime} 22.1^{\prime \prime} \mathrm{E}\end{array}$ & $\begin{array}{l}\text { Tamarakki } \\
\text { Vadakkur }\end{array}$ & Sivagangai & Sivagangai & Tamil Nadu \\
\hline 5 & $\begin{array}{l}10^{\circ} 59.8^{\prime \prime} \mathrm{N} \\
77^{\circ} 30.5^{\prime \prime} \mathrm{E}\end{array}$ & Vadasinnapalayam & Kangeyam & Tiruppur & Tamil Nadu \\
\hline 6 & $\begin{array}{l}11^{\circ} 02.35^{\prime \prime} \mathrm{N} \\
77^{\circ} 35.93^{\prime \prime} \mathrm{E}\end{array}$ & Pappini & Kangeyam & Tiruppur & Tamil Nadu \\
\hline 7 & $\begin{array}{l}11^{\circ} 6.15^{\prime \prime} \mathrm{N} \\
77^{\circ} 39.55^{\prime \prime} \mathrm{E}\end{array}$ & Palaiyakottai & Kangeyam & Tiruppur & Tamil Nadu \\
\hline \multicolumn{6}{|c|}{ AESR: 3, Karnataka plateau (Rayalseema as inclusion), hot arid ESR } \\
\hline 8 & $\begin{array}{l}14^{\circ} 36^{\prime} 11.7^{\prime \prime} \mathrm{N} \\
77^{\circ} 21^{\prime} 14.3^{\prime \prime} \mathrm{E}\end{array}$ & Muttala-1 & Atmakur & Anantapur & Andhra Pradesh \\
\hline 9 & $\begin{array}{l}14^{\circ} 36^{\prime} 19.4^{\prime \prime} \mathrm{N} \\
77^{\circ} 22^{\prime} 7.7^{\prime \prime} \mathrm{E}\end{array}$ & Muttala-2 & Atmakur & Anantapur & Andhra Pradesh \\
\hline 10 & $\begin{array}{l}14^{\circ} 45.22 \mathrm{~N}, \\
77^{\circ} 40^{\prime} 804^{\prime \prime} \mathrm{E}\end{array}$ & Bodagandodi & $\begin{array}{l}\text { Bukkarayasa } \\
\text { mudhrum }\end{array}$ & Anantapur & Andhra Pradesh \\
\hline 11 & $\begin{array}{l}14^{\circ} 46.389 \mathrm{~N}, \\
77^{\circ} 45^{\prime} 611^{\prime \prime} \mathrm{E}\end{array}$ & Kottapalle & $\begin{array}{l}\text { Bukkarayasa } \\
\text { mudhrum }\end{array}$ & Anantapur & Andhra Pradesh \\
\hline 12 & $\begin{array}{l}14^{\circ} 41.931 \mathrm{~N}, \\
77^{\circ} 42^{\prime} 621^{\prime \prime} \mathrm{E}\end{array}$ & Dayyadakuntapalle & $\begin{array}{l}\text { Bukkarayasa } \\
\text { mudhrum }\end{array}$ & Anantapur & Andhra Pradesh \\
\hline 13 & $\begin{array}{l}14^{\circ} 44.316 \mathrm{~N}, \\
77^{\circ} 36^{\prime} 116^{\prime \prime} \mathrm{E}\end{array}$ & Chennampalle & $\begin{array}{l}\text { Bukkarayasa } \\
\text { mudhrum }\end{array}$ & Anantapur & Andhra Pradesh \\
\hline
\end{tabular}

\section{Biophysical characterisation}

Soil profile studies were carried out in selected sites up to $200 \mathrm{~cm}$ or to the depth limited by rock and studied in detail for morphological and physical characteristics. Site and soil characteristics were recorded for all profile sites as per the standard guidelines (Soil Survey Staff 1993). The major desertification processes identified in the study area were soil erosion, salinisation/alkalinisation, vegetal 
degradation and deterioration of soil fertility. Soil samples from representative profiles were collected for laboratory characterization to identify the major soil indicators responsible for desertification processes.

\section{Laboratory characterization}

The soil samples were air dried and processed for laboratory analysis. Soil texture was determined as per international pipette method (Piper 1966). Organic carbon was estimated by Walkley and Black (1934) method. The soil reaction (1:2.5 soil water suspension), electrical conductivity and cation exchange capacity were determined by standard procedures (Jackson 1973). Nutrient properties like available nitrogen (Subbiah and Asija 1956), available phosphorous (Olsen et al. 1954) and available potassium (Neutral normal ammonium acetate method) were analyzed.

\section{Statistical analysis}

PCA was carried out in R software using prcomp package to identify the indicators which explain maximum variance using Eigen value. The indicators selected from the PCA was subjected to linear discriminant analysis (LDA) using R software in order to identify the most important

Table 3. Climatic parameters factor responsible for desertification. The field observation and laboratory data are considered as factors for desertification assessment and considered as independent variable. Based on the intensity, degree of desertification vulnerability was classified into 5 classes (very high, high, medium, low, very low or none) and it was used as dependent variable for LDA analysis.

\section{Results and Discussion \\ Climatic indicators}

Analysis of climatic parameters revealed that air temperature, rainfall, potential evapo-transpiration and aridity index are major climatic factors responsible for desertification processes (Table 3). Maximum air temperature ranged from 31.6 to $35.3^{\circ} \mathrm{C}$ and minimum temperature ranged from 21.9 to $25.5^{\circ} \mathrm{C}$. The highest temperature $\left(35.3^{\circ} \mathrm{C}\right)$ and potential evapotranspiration is recorded in Nanguneri $(1879 \mathrm{~mm})$. Lowest rainfall was recorded in Kangeyam (493 $\mathrm{mm}$ ) followed by Bukkarayasamudhrum $(556 \mathrm{~mm})$. Aridity index was calculated from average precipitation and potential evapotranspiration as per UNEP, 1992. The aridity index in the study sites ranged from 0.29 to 0.52 . Overall, AESR 3 recorded lowest rainfall and aridity index compared to AESR 8.3 .

\begin{tabular}{cccccc} 
Site & Air temperature & $\left({ }^{\circ} \mathbf{C}\right)$ & $\begin{array}{c}\text { Potential } \\
\text { evapotranspiration } \\
(\mathbf{m m})\end{array}$ & $\begin{array}{c}\text { Rainfall } \\
(\mathbf{m m})\end{array}$ & $\begin{array}{c}\text { Aridity } \\
\text { index }\end{array}$ \\
\hline AESR 8.3 & 35.3 & 22.7 & 1879.8 & 669.4 & 0.36 \\
1 & 35.3 & 22.7 & 1879.8 & 669.4 & 0.36 \\
2 & 31.6 & 25.5 & 1521.9 & 786 & 0.52 \\
$\mathbf{3}$ & 31.6 & 25.5 & 1521.9 & 786 & 0.52 \\
$\mathbf{4}$ & 33.5 & 25.5 & 1684.9 & 493 & 0.29 \\
5 & 33.5 & 25.5 & 1684.9 & 493 & 0.29 \\
6 & 33.5 & 25.5 & 1684.9 & 493 & 0.29 \\
7 & & & & \\
AESR 3 & 33.3 & 21.9 & 1737 & 574 & 0.33 \\
8 & 33.3 & 21.9 & 1737 & 574 & 0.33 \\
9 & 34.4 & 22.9 & 1657 & 556.1 & 0.34 \\
10 & 34.4 & 22.9 & 1657 & 556.1 & 0.34 \\
11 & 34.4 & 22.9 & 1657 & 556.1 & 0.34 \\
12 & 34.4 & 22.9 & 1657 & 556.1 & 0.34 \\
13 & & & & &
\end{tabular}




\section{Soil physical indicators}

Soil erosion, drainage, gravelliness, soil depth, surface horizon thickness, slope are the major physical indicators considered for desertification in the study area. The morphological characteristics of selected soils are given in Table. 4. The upland soils in AESR 8.3 are shallow to moderately deep, well drained with moderate to severe erosion occurring on very gently sloping lands. Lowland soils are very deep, poorly drained having waterlogging constraints. The upland soils of AESR 3.0 are moderately shallow to moderately deep, well drained soils with moderate to severe erosion occurring on very gently to gently sloping lands. The lowlands soils are deep, moderately well drained occurring in nearly level agriculture lands. The shrub and forest land soils in AESR 3.0 are having shallow, well drained with severe erosion problems.

Table 4. Morphological characteristics of selected soils

\begin{tabular}{|c|c|c|c|c|c|c|c|c|}
\hline $\begin{array}{l}\text { Sampling } \\
\text { site }\end{array}$ & $\begin{array}{l}\text { Landfor } \\
\text { m }\end{array}$ & $\begin{array}{l}\text { Slope } \\
(\%)\end{array}$ & Drainage & Erosion & $\begin{array}{l}\text { Surface } \\
\text { fragment } \\
\text { s }(\%)\end{array}$ & $\begin{array}{l}\text { Land } \\
\text { use }\end{array}$ & $\begin{array}{l}\text { Depth } \\
\text { (cm) }\end{array}$ & $\begin{array}{l}\text { Surface } \\
\text { horizon } \\
\text { thickness } \\
\text { (cm) }\end{array}$ \\
\hline \multicolumn{9}{|c|}{ AESR: 8.3, Tamil Nadu uplands and plains hot moist semi -arid ESR } \\
\hline 1 & uplands & $1-3$ & $\begin{array}{l}\text { moderately } \\
\text { well }\end{array}$ & moderate & $0-15$ & Fallow & $50-75$ & 17 \\
\hline 2 & Plains & $0-1$ & $\begin{array}{l}\text { well } \\
\text { drained }\end{array}$ & slight & - & Fallow & $\begin{array}{l}100- \\
150\end{array}$ & 20 \\
\hline 3 & uplands & $1-3$ & $\begin{array}{l}\text { well } \\
\text { drained }\end{array}$ & severe & $35-60$ & $\begin{array}{l}\text { Agricult } \\
\text { ure }\end{array}$ & $>150$ & 10 \\
\hline 4 & lowlands & $0-1$ & $\begin{array}{l}\text { Poorly } \\
\text { drained }\end{array}$ & $\begin{array}{l}\text { Very } \\
\text { slight }\end{array}$ & - & Fallow & $>150$ & 10 \\
\hline 5 & uplands & $1-3$ & $\begin{array}{l}\text { well } \\
\text { drained }\end{array}$ & severe & $0-15$ & fallow & $25-50$ & 13 \\
\hline 6 & uplands & $0-1$ & $\begin{array}{l}\text { well } \\
\text { drained }\end{array}$ & slight & $15-35$ & $\begin{array}{l}\text { Grasslan } \\
\text { ds }\end{array}$ & $50-75$ & 13 \\
\hline 7 & upland & $1-3$ & $\begin{array}{l}\text { well } \\
\text { drained }\end{array}$ & moderate & $15-35$ & $\begin{array}{l}\text { Grasslan } \\
\text { ds }\end{array}$ & $75-100$ & 22 \\
\hline \multicolumn{9}{|c|}{ AESR: 3, Karnataka plateau (Rayalseema as inclusion), hot arid ESR } \\
\hline 8 & uplands & $3-5$ & $\begin{array}{l}\text { well } \\
\text { drained }\end{array}$ & severe & $15-35$ & $\begin{array}{l}\text { Agricult } \\
\text { ure }\end{array}$ & $50-75$ & 13 \\
\hline 9 & lowlands & $0-1$ & $\begin{array}{l}\text { moderately } \\
\text { well }\end{array}$ & slight & - & $\begin{array}{l}\text { Agricult } \\
\text { ure }\end{array}$ & $\begin{array}{l}100- \\
150\end{array}$ & 18 \\
\hline 10 & uplands & $1-3$ & well & moderate & $35-60$ & $\begin{array}{l}\text { Agricult } \\
\text { ure }\end{array}$ & $75-100$ & 11 \\
\hline 11 & lowlands & $0-1$ & $\begin{array}{l}\text { moderately } \\
\text { well }\end{array}$ & $\begin{array}{l}\text { Very } \\
\text { slight }\end{array}$ & - & Fallow & $\begin{array}{l}100- \\
150\end{array}$ & 16 \\
\hline 12 & $\begin{array}{l}\text { Sloping } \\
\text { lands }\end{array}$ & $3-5$ & $\begin{array}{l}\text { Well } \\
\text { drained }\end{array}$ & severe & $15-35$ & Shrub & $25-50$ & 10 \\
\hline 13 & $\begin{array}{l}\text { Sloping } \\
\text { hills and } \\
\text { ridges }\end{array}$ & $8-15$ & $\begin{array}{l}\text { Well } \\
\text { drained }\end{array}$ & severe & $35-60$ & Forest & $25-50$ & 15 \\
\hline
\end{tabular}

Soil chemical indicators

Soil physio-chemical properties like $\mathrm{pH}, \mathrm{EC}$, organic carbon, CEC and nutrient properties like available N, P and K are selected as major soil chemical parameters for desertification assessment (Table.5). The soil $\mathrm{pH}$ is ranged from 5.82 to 9.1 in AESR 8.3 and 7.06 - 8.73 in AESR 3.0. Soils are strongly alkaline $(8.5-9.0)$ in Rajakkamangalam, 
Tamarakkivadakkur, Pappini and Kottapalle sites. Except Nanguneri, Malampatti and Muttala-1, the remaining soils are moderately alkaline. The soils are non saline with a EC ranged from 0.01 to $1.34 \mathrm{dsm}^{-1}$. Organic carbon content ranged from 0.24 to $0.95 \%$ in AESR 8.3 and 0.15 to $1.57 \%$ in
AESR 3.0. Cation exchange capacity varied from 5.4 to 24.5 $\mathrm{C}$ mol $(\mathrm{p}+) \mathrm{kg}^{-1}$ in AESR 8.3 and 8.8 to 35.1 in AESR 3.0. Available Nitrogen, Phosphorus and Potassium content ranged from 109.7 to $265 \mathrm{~kg} \mathrm{ha}^{-1}, 1.64$ to $51.0 \mathrm{~kg} \mathrm{ha}^{-1}$ and 94.0 to $559.0 \mathrm{~kg} \mathrm{ha}^{-1}$ respectively.

Table 5. Physical and chemical characteristics of selected soils

\begin{tabular}{|c|c|c|c|c|c|c|c|c|c|c|}
\hline \multirow{2}{*}{$\begin{array}{c}\text { Sampling } \\
\text { site }\end{array}$} & \multirow{2}{*}{$\begin{array}{c}\text { Sand } \\
(\%)\end{array}$} & \multirow{2}{*}{$\begin{array}{l}\text { Silt } \\
(\%)\end{array}$} & \multirow{2}{*}{$\begin{array}{l}\text { Clay } \\
(\%)\end{array}$} & \multirow[b]{2}{*}{ pH } & \multirow{2}{*}{$\underset{\left(\mathrm{dsm}^{-1}\right)}{\mathrm{EC}}$} & \multirow{2}{*}{$\begin{array}{l}\text { OC } \\
(\%)\end{array}$} & \multirow{2}{*}{$\begin{array}{c}\text { CEC } \\
\left(\mathrm{cmol}^{-1}+\right. \\
\left.) \mathrm{kg}^{-1}\right)\end{array}$} & $\mathbf{N}$ & $\mathrm{P}$ & $\mathrm{K}$ \\
\hline & & & & & & & & \multicolumn{3}{|c|}{$\left(\mathrm{kgha}^{-1}\right)$} \\
\hline \multicolumn{11}{|c|}{ AESR: 8.3, Tamil Nadu uplands and plains hot moist semi -arid ESR } \\
\hline 1 & 44.8 & 10 & 45.2 & 6.38 & 0.149 & 0.596 & 5.4 & 265 & 28.5 & 175.8 \\
\hline 2 & 66.2 & 4 & 29.8 & 8.68 & 0.157 & 0.954 & 5.9 & 132 & 17.93 & 559 \\
\hline 3 & 73 & 6.5 & 20.5 & 5.8 & 0.01 & 0.46 & 7.9 & 162 & 22.6 & 201.6 \\
\hline 4 & 54.3 & 10.5 & 35.2 & 9.1 & 1.34 & 0.52 & 24.5 & 132 & 25.6 & 184.8 \\
\hline 5 & 70.2 & 12.2 & 17.6 & 8.24 & 0.14 & 0.24 & 14.4 & 232 & 7.3 & 353 \\
\hline 6 & 72.4 & 8.6 & 19 & 8.74 & 0.26 & 0.39 & 10 & 265 & 28.5 & 175.8 \\
\hline 7 & 75.2 & 9.6 & 15.4 & 8.16 & 0.29 & 0.32 & 13.1 & 145 & 13.18 & 100.80 \\
\hline \multicolumn{11}{|c|}{ AESR: 3, Karnataka plateau (Rayalseema as inclusion), hot arid ESR } \\
\hline 8 & 62.4 & 22.0 & 14.4 & 7.06 & 0.01 & 1.47 & 8.8 & 119 & 51.0 & 100.4 \\
\hline 9 & 47.2 & 24.8 & 19.6 & 8.03 & 0.19 & 0.15 & 9.6 & 141 & 12.3 & 252.0 \\
\hline 10 & 46.4 & 39.8 & 13.7 & 8.2 & 1.24 & 0.420 & 19.5 & 109 & 12.03 & 94.08 \\
\hline 11 & 41.4 & 9.4 & 49.2 & 8.73 & 0.128 & 0.46 & 35.1 & 109 & 1.64 & 117.6 \\
\hline 12 & 65.99 & 23.21 & 10.80 & 8.31 & 0.85 & 0.42 & 12.9 & 188 & 7.59 & 352.8 \\
\hline 13 & 57.4 & 26.7 & 14.9 & 7.98 & 0.118 & 0.53 & 13.3 & 125 & 2.34 & 123.52 \\
\hline
\end{tabular}

\section{Selection of Indicators}

Soil erosion is the major desertification process in eight study sites with moderate to severe erosion. Severe erosion is reported in degraded forest, shrub, grazing lands and fallow lands. Four sites are affected by high alkalinity (Rajakkamangalam, Tamarakkivadakkur, Pappini and Kottapalle). Vegetal degradation was observed in Dayyadakuntapalle, Chennampalle, Pappini and Palaiyakottai sites. With respect to soil nutrient availability, available Nitrogen is low $\left(<280 \mathrm{kgha}^{-1}\right)$ in all the sites and OC is low in eight sites $(<0.5 \%)$. Phosphorous is low $(<11$ $\mathrm{kg} / \mathrm{ha}$ ) in Nanguneri, Vadasinnapalayam, Kottapalle, Dayyadakuntapalle and Chennampalle sites whereas available $\mathrm{K}$ is low $(<118 \mathrm{~kg} / \mathrm{ha})$ in Palaiyakottai. Muttala-1 and Bodagandodi.
Seventeen indicators were selected for principal component analysis representing climate, soil physical and chemical factors. Evapo-transpiration, rainfall and aridity index were selected as climatic indicators, soil erosion, drainage, depth, slope, surface horizon thickness, sand, clay were identified as soil physical indicators whereas $\mathrm{pH}, \mathrm{EC}$, OC, CEC and available N P K were selected as chemical indicators.

PCA analysis

Principal component analysis was carried out with all seventeen selected biophysical indicators. The group was reduced to few indicators which explain maximum variance using Eigen value. The principal components were selected based on Eigen value $(>1)$ and cumulative variance (Rajan et 
al. 2010 and Adhikari et al. 2011). The biophysical indicator with highest loading was selected from each principal component with due representation to climatic, physical and chemical factors (Table 6). There are 5 principal components with more than one Eigen value which are responsible for variation of $79.9 \%$ created by desertification processes. Remaining 12 components are responsible for only $20 \%$ of variation and therefore they are rejected. The first component accounted for $27.45 \%$ variance with the highest loadings was found in soil physical factors like drainage (0.409), erosion (-0.377) and soil depth (0.363). The second component accounted for $19.45 \%$ variance and highest loadings were found in evapo-transpiration (0.396) and surface thickness $(0.395)$. The third principal component accounted for $14.50 \%$ variance in that organic carbon ($0.439)$ and phosphorous (-0.455) have higher loadings. Both PC4 and PC5 are responsible for variance of $17.8 \%$. Since, the components in $\mathrm{PC} 1$ have more variance, erosion, drainage and depth were selected from PC1, surface horizon thickness and evapo-transpiration having highest loadings were selected from PC2 and organic carbon and phosphorous were selected from PC3. One indicator each was selected from PC4 (sand) and PC5 (pH).

Table 6. Rotated principal components of biophysical indicators desertification

\begin{tabular}{lccccc}
\hline Variables & PC1 & PC2 & PC3 & PC4 & PC5 \\
\hline ET & -0.087 & $\mathbf{0 . 3 9 6}$ & -0.339 & -0.079 & 0.036 \\
Rainfall & 0.299 & -0.296 & -0.254 & 0.097 & -0.023 \\
Aridity index & 0.288 & -0.389 & -0.103 & 0.107 & -0.032 \\
Gravels & -0.296 & -0.356 & 0.098 & -0.120 & -0.047 \\
depth & $\mathbf{0 . 3 6 3}$ & -0.191 & -0.065 & 0.093 & 0.122 \\
Slope & -0.254 & -0.151 & 0.060 & -0.398 & 0.001 \\
Drainage & $\mathbf{0 . 4 0 9}$ & 0.033 & 0.034 & -0.143 & -0.180 \\
Erosion & $\mathbf{- 0 . 3 7 7}$ & -0.220 & -0.101 & 0.028 & -0.105 \\
Sand & -0.234 & -0.106 & -0.071 & $\mathbf{0 . 5 2 4}$ & 0.156 \\
Clay & 0.336 & 0.174 & -0.176 & -0.174 & -0.267 \\
Ph & 0.111 & 0.258 & 0.399 & 0.110 & $\mathbf{0 . 5 9 9}$ \\
EC & 0.179 & -0.154 & 0.365 & 0.082 & 0.173 \\
OC & -0.040 & -0.075 & $\mathbf{- 0 . 4 3 9}$ & -0.187 & 0.484 \\
N & -0.108 & 0.125 & -0.128 & 0.359 & -0.381 \\
P & 0.017 & -0.150 & $\mathbf{- 0 . 4 5 5}$ & 0.013 & 0.142 \\
K & 0.017 & 0.193 & -0.122 & 0.507 & 0.205 \\
Surface horizon thickness & -0.026 & $\mathbf{0 . 3 9 5}$ & -0.147 & -0.156 & 0.102 \\
Eigen value & 4.67 & 3.31 & 2.46 & 1.71 & 1.32 \\
Variance & 27.45 & 19.45 & 14.50 & 10.07 & 7.77 \\
Cumulative Variance & 27.45 & 46.90 & 61.40 & 71.47 & 79.24 \\
\hline
\end{tabular}

\section{Linear Discriminant Analysis}

Linear discriminant analysis was carried out to identify the major factors responsible for desertification process. Desertification ratings calculated from field observations were used as dependant variable. The most discriminating factor was selected from the variables identified from PCA analysis. The results are presented in Table. 7. As per linear discriminant coefficient, the highest 
value was observed for $\mathrm{pH}(-2.701)$ followed by organic carbon (-1.460) and drainage (1.340). Soil $\mathrm{pH}$ is found as the most important indicator of desertification in arid and semi arid agro region. Poor drainage associated with high evapotranspiration in the study sites accumulates salt in the surface area, leads to soil chemical degradation/ alkalinsation. Soil organic carbon emerged as the second reliable indicator of desertification, since it plays vital role in soil function.
Rajan et al. (2013) and Dlamini et al. (2014) suggested that organic carbon can be used for monitoring land degradation. Loss of organic matter due to soil erosion describes the importance of soil organic carbon in identifying desertification. Soil erosion, land use, land management and climate are the cause for the organic carbon loss. Therefore, $\mathrm{pH}$ and organic carbon are considered as major indicators for monitoring desertification processes in arid and semi arid region of south India.

Table 7. Coefficients of linear discriminate analysis for selected biophysical indicators

\begin{tabular}{lr}
\hline \multicolumn{1}{c}{ Variable } & Coefficient \\
\hline ET & -0.037 \\
depth & -0.081 \\
Sand & -0.030 \\
Erosion & -1.119 \\
Drainage & 1.340 \\
OC & -1.460 \\
P & 0.046 \\
pH & -2.701 \\
Surface horizon thickness & 0.315 \\
\hline
\end{tabular}

\section{Conclusion}

Identification of biophysical indicators responsible for desertification is necessary for periodical monitoring and preparation of strong combating plan. A total of 17 biophysical indicators were analysed in 13 sites of South India to identify the important indicators using principal component analysis and linear discriminate analysis. Among different variables, $\mathrm{pH}$ and organic carbon are the most reliable indicators for assessing the degree of desertification processes in South India.

\section{Reference}

Adhikari P., Shukla M.K., Mexal J.G., and Sharma P. (2011). Assessment of the Soil Physical and Chemical Properties of Desert Soils Irrigated With Treated Wastewater Using Principal Component Analysis. Soil Science 176: 1-11.

Bergkamp G. (1995) A hierarchical approach for desertification assessment. Environmental
Monitoring Assessment 37, 59-78. doi: 10.1007/BF00546880

Dlamini Phesheya, Chivenge Pauline, Manson Alan and Chaplot Vincent. (2014). Land degradation impact on soil organic carbon and nitrogen stocks of subtropical humid grasslands in South Africa. Geoderma 235-236; 372-381.

Higginbottom T.P. and Symeonakis, E. (2016). Assessing Land Degradation and Desertification Using Vegetation Index Data: Current Frameworks and Future Directions. Remote Sensing 6, 9552-9575; doi:10.3390/rs6109552.

Jackson M.L. (1973). Soil Chemical Analysis. Prentice Hall of India Pvt. Ltd. New Delhi.

Kosmas C., Ferrara A., Briasouli H. and Imeson A. (1999). Methodology for mapping Environmentally Sensitive Areas (ESAs) to Desertification. In: The Medalus project: Mediterranean desertification and land use Manual on key indicators of desertification and mapping environmentally sensitive areas to desertification. In: Kosmas C, 
Kirkby M, Geeson N (eds), European Union 18882, ISBN 92-828-6349-2, pp 31-47.

Kosmas C., Kairis O., Karavitis C., Acikalin S., Alcalá M., Alfama P., Atlhopheng J., Barrera J., Belgacem A., Solé-Benet A., Brito J., Chaker M., Chanda R., Darkoh M., Ermolaeva O., Fassouli V., Fernandez F., Gokceoglu C., Gonzalez D., Gungor H., Hessel R., Khatteli H.,. Khitrov N, Kounalaki A., Laouina A., Magole L., Medina L., Mendoza M., Mulale K., Ocakoglu F., Ouessar M., Ovalle C., Perez C., Perkins J., Pozo A., Prat C., Ramos A., Ramos J., Riquelme,J., Ritsema C., Romanenkov V., Sebego R., Sghaier M., Silva N., Sizemskaya M., Sonmez H., Taamallah H., Tezcan L., de Vente,J., Zagal E., Zeiliguer A. and Salvati L. (2015). An exploratory analysis of land abandonment drivers in areas prone to desertification, Catena 128, 256-261.

Naidu L.G.K., Dharumarajan S., Lalitha M., Srinivas S., Ramamurthy V., and Singh S.K. (2014). Categorisation and delineation of prime and marginal lands of Andhra Pradesh for different uses. Agropedology 24, 253-261.

Olsen S.R., Cole C.V., Watanabe F.S. and Dean L.A. (1954). Estimation of Available Phosphorus in Soils by Extraction with Sodium Bicarbonate. U. S. Department of Agriculture Circular No. 939.

Piper C.S. (1966). Soil and Plant Analysis. Hans Publisher, Bombay.

Rajan K., Natarajan A., Anil Kumar K.S., Badrinath M.S. and Gowda R.C. (2010). Soil organic carbon-the most reliable indicator for monitoring land degradation by soil erosion. Current science 99, 823-827.

SAC. (2016). Desertification and Land Degradation Atlas of India (Based on IRS AWiFS data of 2011-13 and 2003-05), Space Applications Centre, ISRO, Ahmedabad, India, 219.

Salvati L. and Zitti M. (2008). Assessing the impact of ecological and economic factors on land degradation vulnerability through multiway analysis. Ecological Indicators 9, 357-363.

Salvati L., Mancini A., Bajocco S. Roberta Gemmiti Margherita Carlucci. (2011). Socioeconomic development and vulnerability to land degradation in Italy. Regional Environmental Change 11, 767. doi:10.1007/s10113-011-0209-x.

Sehgal J.L. and Abrol I.P. (1994). Soil degradation in India: Status and Impact. Oxford Sc IBH Publishing Co. Pvt. Ltd., New Delhi, India 80p.

Sivakumar M.V.K. (2007). Interactions between climate and desertification. Agricultural and Forest Meteorology 142, 143-155.

Soil Survey Staff. (1993). Soil Survey Manual, Agriculture Handbook No.18, USDA, Washington, DC.

Subbiah B.V. and Asija G.L. (1956). A rapid procedure for estimation of available $\mathrm{N}$ in soils. Current Science 25, 149-153.

Walkley A. and Black I.A. (1934). An estimation of the method for determining soil organic matter and a proposed modification of the chromic acid titration method. Soil science 37: 29-38.

Received: August 2016

Accepted: December 2016 